\title{
Cerebrolysin Attenuates Astrocyte Activation Following Repetitive Mild Traumatic Brain Injury: Implications for Chronic Traumatic Encephalopathy
}

\author{
Hyun Bae Kang1, GiHun Kim², HyunJoong $\mathrm{Kim}^{2}$, Sa Rang $\mathrm{Han}^{3}$, Dong Jin Chae ${ }^{3}$, Hee-Jung Song ${ }^{4}$ \\ and Dong Woon $\mathrm{Kim}^{3}$ *
}

${ }^{1}$ Pathogen Resource TF, Center for Infectious Diseases, National Institute of Health, Korea Centers for Disease Contrd \& Prevention, Chungbuk, 363-951, Korea

${ }^{2}$ Department of Biology and Department of Microbiology and Biotechnology, Daejeon University, Daejeon 300-716, Korea

${ }^{3}$ Department of Anatomy, Chungnam National University School of Medicine, Daejeon 301-747, Korea

${ }^{4}$ Department of Neurology, Chungnam National University Hospital and School of Medicine, Daejeon 301-721, Korea

Received August 24, 2013 /Revised September 9, 2013 /Accepted September 9, 2013

\begin{abstract}
Chronic traumatic encephalopathy (CTE), which is common in athletes, is a progressive neurodegenerative disease and a long-term consequence of repetitive closed head injuries. CTE is regarded as a chronic brain syndrome due to the effects of repetitive traumatic brain injury (TBI). Because neurotrophic factors are neuroprotective in models of brain and spinal cord injuries, we examined the effects of cerebrolysin, a mixture of various neurotrophic factors, on brain pathology in a mouse model of repetitive mild TBI (rmTBI), which is a good model of CTE. Five groups were created and treated as follows: groups 1 and 2: rmTBI for 4 weeks following cerebrolysin injection for 4 weeks; groups 3 and 4: rmTBI for 8 weeks with or without cerebrolysin injection for 4 weeks; group 5: control. We found that p-tau expression was increased in the pyramidal layer of the cortex and hippocampus, particularly the CA3 region, but not in the CA1 region and the dentate gyrus (DG). Intra-tail vein administration of cerebrolysin $(10 \mu \mathrm{l}$ of $1 \mathrm{mg} / \mathrm{ml})$ after/during rmTBI treatment reduced p-tau expression in both the cortex and hippocampus. Histological analysis revealed mild astrocyte activation (increased expression of glial fibrillary acidic protein (GFAP)) but not microglia activation (ionized calcium binding adaptor molecule 1 (iba-1) expression) and peripheral macrophage infiltration (CD45). Additionally, administration of cerebrolysin after rmTBI resulted in reduced astrocyte activation. These observations in rmTBI demonstrated that cerebrolysin treatment reduces phosphorylation of tau and astrocyte activation, attenuates brain pathology, and mitigates function deficits in TBI. Taken together, our observations suggest that cerebrolysin has potential therapeutic value in CTE.
\end{abstract}

Key words : Chronic traumatic encephalopathy (CTE), traumatic brain injury (TBI), cerebrolysin, phosphorylation of tau

\section{Introduction}

Chronic traumatic encephalopathy (CTE) has been defined as a progressive neurodegenerative disease caused by repetitive head trauma $[20,25]$. CTE was first described in 1928 and has become a popular topic due to its close association with football, hockey, soccer, boxing, and professional wrestling injuries. Many of these affected athletes, mostly retired, have struggled in their later years with depression,

\footnotetext{
*Corresponding author

*Tel : +82-42-580-8207, Fax : +82-42-586-4800

*E-mail : visnu528@cnu.ac.kr

This is an Open-Access article distributed under the terms of the Creative Commons Attribution Non-Commercial License (http://creativecommons.org/licenses/by-nc/3.0) which permits unrestricted non-commercial use, distribution, and reproduction in any medium, provided the original work is properly cited.
}

substance abuse, anger, memory/motor disturbances, and suicide [17]. Autopsy results from these athletes have suggested a link between these emotional, cognitive, and physical manifestations and CTE [15]. Concussion or mild traumatic brain injury (rmTBI) is one of the most common neurologic disorders, accounting for approximately $90 \%$ of all brain injuries sustained [5]. However, rmTBI was underestimated or regarded as benign; in some, the injury was not recognized at all. In a 2009 review concerning CTE, McKee et al. found that 51 neuropathologically diagnosed cases of CTE 46 (90\%) occurred in athletes [15].

Repetitive concussive or subconcussive blows to the head have been recognized to place individuals at risk for CTE $[6,24]$. However, no clear consensus exists regarding how much or little trauma is needed to cause CTE, while it is clear that anyone who experiences repetitive head trauma, regardless of the mechanism, is at risk of developing CTE. 
In a study of repeated head trauma in mice, Kane et al. created an animal model where mice that did not experience severe TBI, but rather rmTBI, were evaluated for CTE-like changes [9]. They reported that exposure of mice to single impacts resulted in very mild injury. Mice recovered consciousness spontaneously, showed normal grooming and social interactions with cage mates, and did not display signs of pain or discomfort or resistance to handling after the procedure. Skull fractures, intracranial bleeding, respiratory arrest, or seizures were rarely observed [9]. Therefore, we used the rmTBI model, which may be suitable for evaluating CTE.

Recent observations have indicated that growth hormones and neurotrophic factors, such as brain-derived neurotrophic factor (BDNF), glial cell-derived neurotrophic factor (GDNF), nerve growth factor (NGF), insulin-like growth factor (IGF), and neurotensin, given alone or in combination for spinal cord or brain traumatic injury, can attenuate cord pathology and improve functional outcome and motor paralysis [21]. Cerebrolysin is a mixture of various peptides and neurotrophic factors and plays a clinically proven neuroprotective role in stroke and Alzheimer's disease [19, 26]. Recently, cerebrolysin, when administered during the early phases of TBI, was reported to confer remarkable neuroprotective effects on brain pathology and sensory-motor functions [23]. Thus, we evaluated the possible neuroprotective role of cerebrolysin in rmTBI, a reliable model of CTE.

\section{Materials and Methods}

\section{Experimental Animals and Lesions}

Male imprinting control region mice (Samtako, Korea) weighing $23-25 \mathrm{~g}$ were used in the present study. Animals were housed in a room under a controlled light/dark cycle (12 h light/12 h dark) at $23^{\circ} \mathrm{C}$. Food and water were available ad libitum All animal-related procedures were conducted in accordance with the guidelines of the Institutional Animal Care and Use Committee of Chungnam National University (CNU-00151). rmTBI animal models were constructed according to a procedure established previously [9]. Briefly, an iron ball (50 g) was the only material used to impact the mouse skull. The bottom of the weight was 1.77 $\mathrm{cm}^{2}$ to restrict the zone of contact to the top of the mouse head between the ears. Weights were dropped vertically through a poly(vinyl chloride) (PVC) guide tube $(3.1 \mathrm{~cm}$ di- ameter $\times 1 \mathrm{~m}$ length). A stage consisting of a slit piece of aluminum foil, held in place by an " $\mathrm{H}$ "-shaped Plexiglas frame (15 cm length $\times 9 \mathrm{~cm}$ width $\times 23 \mathrm{~cm}$ depth) held subjects in place. In this fashion, the slit foil just supports the body weight of a mouse $(22-25 \mathrm{~g})$ with little or no resistance or restraint upon impact. A sponge cushion $(15 \mathrm{~cm}$ length $\times 9 \mathrm{~cm}$ width $\times 13 \mathrm{~cm}$ depth) is located $10 \mathrm{~cm}$ below the aluminum foil stage to receive the falling mouse, while the weight remains tethered above the free-moving body of the animal. Immediately upon impact, mice were withdrawn to prevent re-hits by the weight as subjects recoiled from the impact-induced compression of the cushion, causing secondary injuries to the brain and spinal cord.

Mice were lightly anesthetized with isoflurane (i.e., until unresponsive to paw or tail pinch) and placed immediately under the vertical PVC tube. Mice were then suspended chest-down on a slit piece of aluminum foil $10 \mathrm{~cm}$ above a foam cushion. Each mouse was quickly positioned so that its head was directly in the path of the falling weight by first resting the weight on the scalp midline between the bregma and lambda. Incisions in the scalp or emplacement of a protective skull helmet were not necessary. The weight was then pulled rapidly upward by an attached string to the desired drop distance and released. Immediately upon impact, the mouse fell freely onto the foam cushion. In this arrangement, the impact-induced acceleration and fall always involved a $180^{\circ}$ horizontal rotation of the mouse body. The mouse was moved immediately to a holding cage to recover.

\section{Tissue Preparation}

To assess the effect of cerebrolysin on rmTBI, mice were administrated $10 \mu \mathrm{l}(1 \mathrm{mg} / \mathrm{ml}$, intra-tail vein) of cerebrolysin (Ever NeuroPharma, Austria) using an insulin syringe. At 4 or 8 weeks after rmTBI with or without cerebrolysin injection (Fig. 1), mice were anesthetized with sodium pentobarbital (50 mg/kg, intraperitoneally), and perfused transcardially with heparinized phosphate-buffered saline (PBS), followed by perfusion with $4 \%$ paraformaldehyde in PBS. Their brains were removed, immersed in the same fixative for $4 \mathrm{~h}$, and then cryoprotected in a 30\% sucrose solution. They were embedded in tissue freezing medium (OCT compound) and then frozen rapidly in 2-methyl butane precooled to its freezing point with liquid nitrogen. Frozen coronal sections (40 $\mu$ l thick) were obtained using a Leica cryostat. Alternate sections were mounted on gelatin-coated 


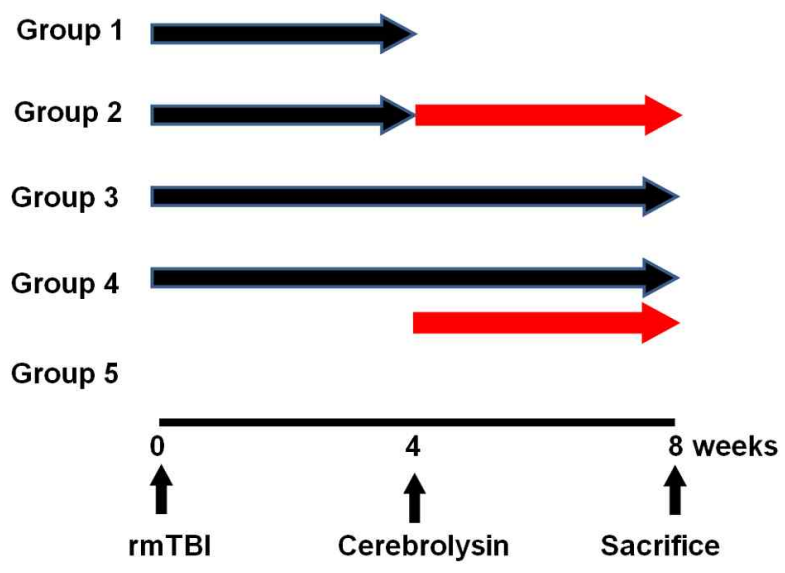

Fig. 1. Timepoints of rmTBI and cerebrolysin treatment.

slides or stored free-floating in antifreeze buffer. Sections mounted on gelatin-coated slides were stained with cresyl violet for routine histological examination. The stored free-floating sections were processed using immunohistochemical techniques.

\section{Immuonohistochemistry}

Parallel free-floating sections were subjected to endogenous peroxidase blocking with $1 \% \mathrm{H}_{2} \mathrm{O}_{2}$ in PBS, followed by treatment with blocking buffer $(1 \%$ fetal bovine serum [FBS] in PBS and $0.3 \%$ Triton X-100 for $30 \mathrm{~min})$ and incubation with primary antibody: p-tau (1:100, \#sc-101817, Santa Cruz), glial fibrillary acidic protein; (GFAP, 1:1000, \#AM020, Biogenex), Iba-1 (1:500, \#019-19741, Wako), CD45 (1:100, \#M0701, Dako). Immunohistochemical staining of the tissue sections were performed using the avidin - biotin peroxidase complex (ABC) method described previously $[10,11$, 28]. After washing with PBS, tissues were exposed to biotinylated anti-rabbit IgG and streptoavidin peroxidase complex (Vector, USA). Immunostaining was visualized with diaminobenzidine (DAB) and mounted using Polymount (Polysciences, USA).

\section{Image Analysis}

To assess the immunohistochemical signals quantitatively, we used the NIH image program (ImageJ) for densitometric measurements. Quantitative data was analyzed using $t$-test to determine the statistical significance, which was accepted for $\mathrm{P}$ values of $*<0.05$.

\section{Results}

Increases in phospho-tau could be an early sign of CTE, a hallmark neuropathological index that is now being associated with professional athletes exposed to multiple, mild concussive injuries during their careers $[15,18]$. Therefore, we evaluated the temporal and cellular pattern of p-tau expression. In group 1, p-tau insulin receptor expression was intense in the deep layer (IV-V) but only occasional in the superficial layer (II-III) of the cortex. In group 2, the p-tau insulin expression pattern was similar to that of group 1 , albeit at a lower level. However, p-tau insulin receptor expression peaked in group 3, and then decreased in groups 4 and 5 . In the CA1 of the hippocampus after rmTBI, p-tau+ cells were scattered in the stratum oriens (SO), stratum pyramidale (SP), and stratum radiatum (SR) in groups 1 and 3 , but were rare in groups 2, 4, and 5. In the DG of the hippocampus after rmTBI, p-tau insulin receptor expression was not found in the granular cell layer (GCL), molecular layer (ML), and subgranular zone (SGZ), except for the hilus. In the CA3 of the hippocampus after rmTBI, p-tau insulin receptor expression was observed in group 1 but was decreased in group 2. However, p-tau insulin receptor expression was considerable in group 3 but decreased in groups 4 and 5 (A-E4). p-Tau insulin receptor expression in the CA3 showed a punctuate, perinuclear, cytoplasmic distribution (Fig. 2). Quantitative analysis of p-tau expression after rmTBI with or without cerebrolysin treatment showed significant differences among the CA3 regions (Fig. 3).

Because p-tau IR was found in the CA3 region of the hippocampus after rmTBI, we examined whether a selective lesion or neurodegeneration occurred in the CA3 region using cresyl violet staining to assess neuronal survival. In both groups, pyramidal cell degeneration was not found (Fig. $4 \mathrm{~A}$ ). Next, we evaluated astrocyte and microglia activation after rmTBI with or without cerebrolysin treatment because initial head trauma induces astrocyte and microglial activation, leading to subsequent injury [1]. In groups 2, 4, and 5, GFAP+ astrocytes had tread-like processes and a small cytoplasm. In groups 1 and 3, GFAP+ astrocytes were of mildly activated forms with a hypertrophied cytoplasm and thickened process (Fig. 4B). However, iba-1+ microglia in both groups had a small cytoplasm and a few thin processes. Many iba-1+ microglia were not hypertrophied and aggregated in all groups and exhibited s dense cytoplasm and a round morphology, indicating microglia activation (Fig. 4C). CD45+ macrophages/microglial cells were not observed as activated forms in both groups (Fig. 4D), suggested that 

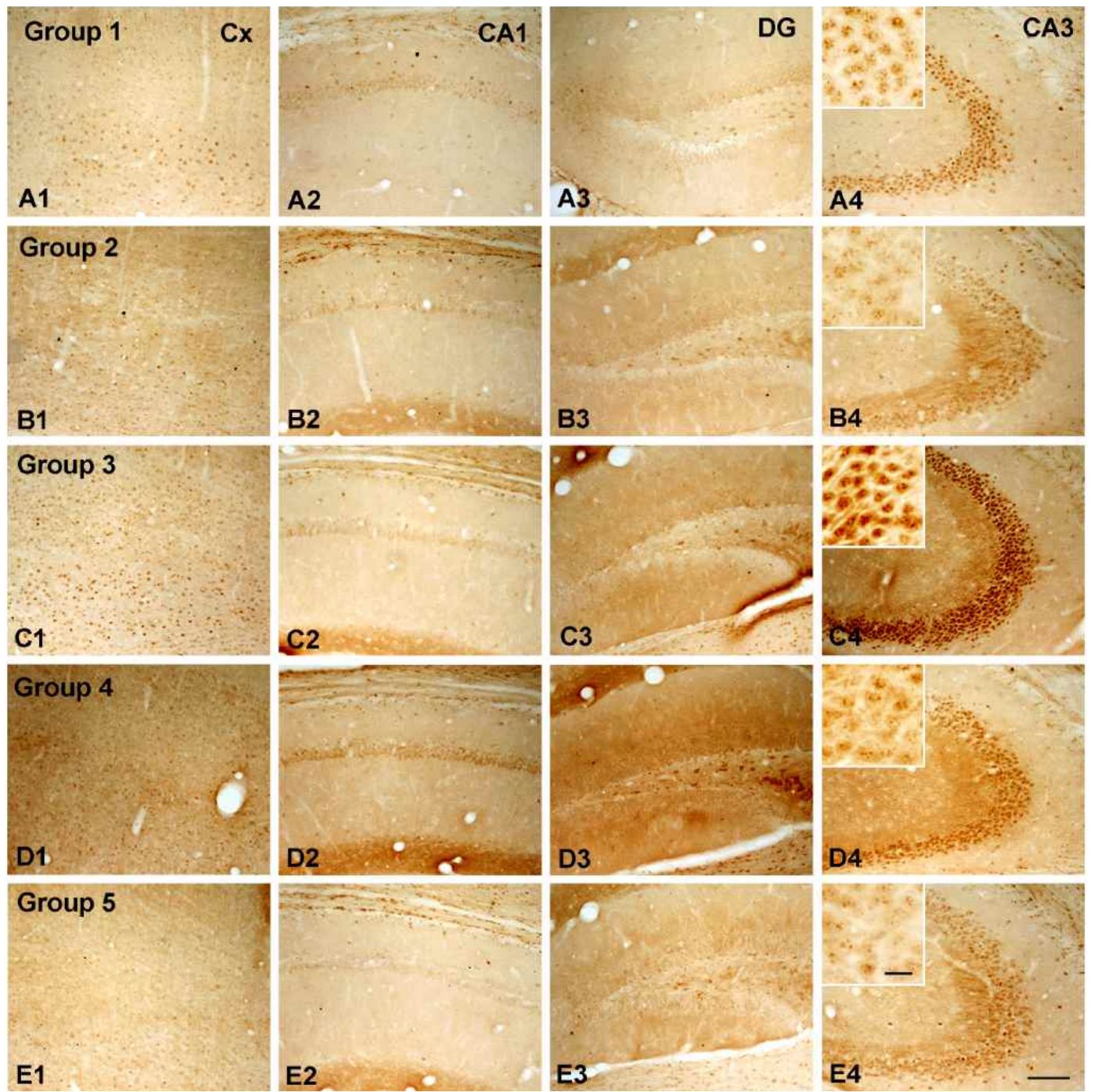

Fig. 2. p-Tau expression in the cerebral cortex, CA1 region, dentate gyrus, and CA3 region of rmTBI. In group 1, p-tau insulin receptor was expressed intensely in the deep layer (IV-V), and occasionally in the superficial layer (II-III), of the cortex. In group 2, the p-tau insulin receptor expression pattern was similar to that in group 1, albeit at a lower level. However, p-tau insulin receptor expression peaked in group 3, and then decreased in groups 4 and 5 (A-E1). In the CA1 region of the hippocampus after rmTBI, p-tau+ cells were scattered in the stratum oriens (SO), stratum pyramidale (SP), and stratum radiatum (SR) in groups 1 and 3 but was rarely found in groups 2, 4, and 5 (A-E2). In the DG of the hippocampus after rmTBI, p-tau insulin receptor expression was not found in the granular cell layer (GCL), molecular layer (ML), and subgranular zone (SGZ), except for the hilus (A-E3). In the CA3 region of the hippocampus after mTBI, p-tau insulin receptor expression was observed in group 1 but was decreased in group 2. However, p-tau insulin receptor was strongly expressed in group 3 , and then was decreased in groups 4 and 4 (A-E4). The rectangular area in A-E4 is a higher magnification view of the CA3 region of each group. p-tau insulin receptor expression in the CA3 region had a punctuate, perinuclear cytoplasmic distribution. Scale bars $=100 \mu \mathrm{m}$ in A-E and $20 \mu \mathrm{m}$ in the rectangular area in A-E4.

no infiltration of peripheral macrophages occurred into the brain parenchyma. The latter finding is consistent with previous reports that the rmTBI model used in our study shows a lack of blood-brain barrier disruption and edema [9]. Quantitative analysis of GFAP expression after rmTBI with or without cerebrolysin treatment showed significant differences among the CA3 regions (Fig. 5).

\section{Discussion}

An increasingly wide variety of experimental animal models are available to investigate secondary injury processes in TBI and provide preclinical data for candidate therapeutic approaches. Broadly, TBI animal models can be divided into two groups: open head injury $(\mathrm{OHI})$ and closed 


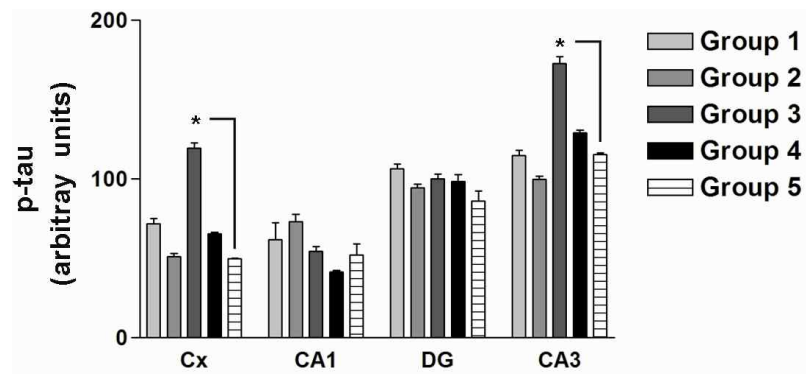

Fig. 3. Image analysis of the relative density of p-tau in the cerebral cortex, CA1 region, dentate gyrus, and CA3 region of rmTBI. The data shown are the means \pm standard deviation obtained from three independent experiments. ${ }^{*} p<0.05$ compared with group 5 .

head injury ( $\mathrm{CHI})$ models. In OHI models, which include the fluid percussion (FP) and controlled cortical impact (CCI) models, the mechanical force is applied directly to the dura mater, which is exposed by a craniotomy. In CHI models, the injury is induced through the intact skull by direct impact (e.g., dropping a weight on the intact skull or striking the intact skull with a piston). Regarding CHI models, weight-drop models that use the gravitational forces of a free-falling weight have been developed for both rats and mice and are among the simplest and most widely used in TBI research [14]. In the Marmarou method, for example, the rodent's head is supported on a thick block of foam or gel that allows partial head acceleration, causing moderate to severe brain injury with diffuse axon injury [4, 14, 27]. However, this model is associated with serious outcomes (i.e., high mortality, skull fracture, and respiratory arrest). To avoid these problems, we used a new murine $\mathrm{CHI}$ model (rmTBI), characterized by a completely unrestrained head and body [9]. In this model, the animal is supported by only a sheet of aluminum foil suspended over an empty case with a thick foam pad at the base. The aluminum foil completely tears off during impact, allowing unrestricted head and body movement of the animal as it falls into the cage. These authors reported that mild concussive injury could be repeatedly induced, suggesting that this technique could be
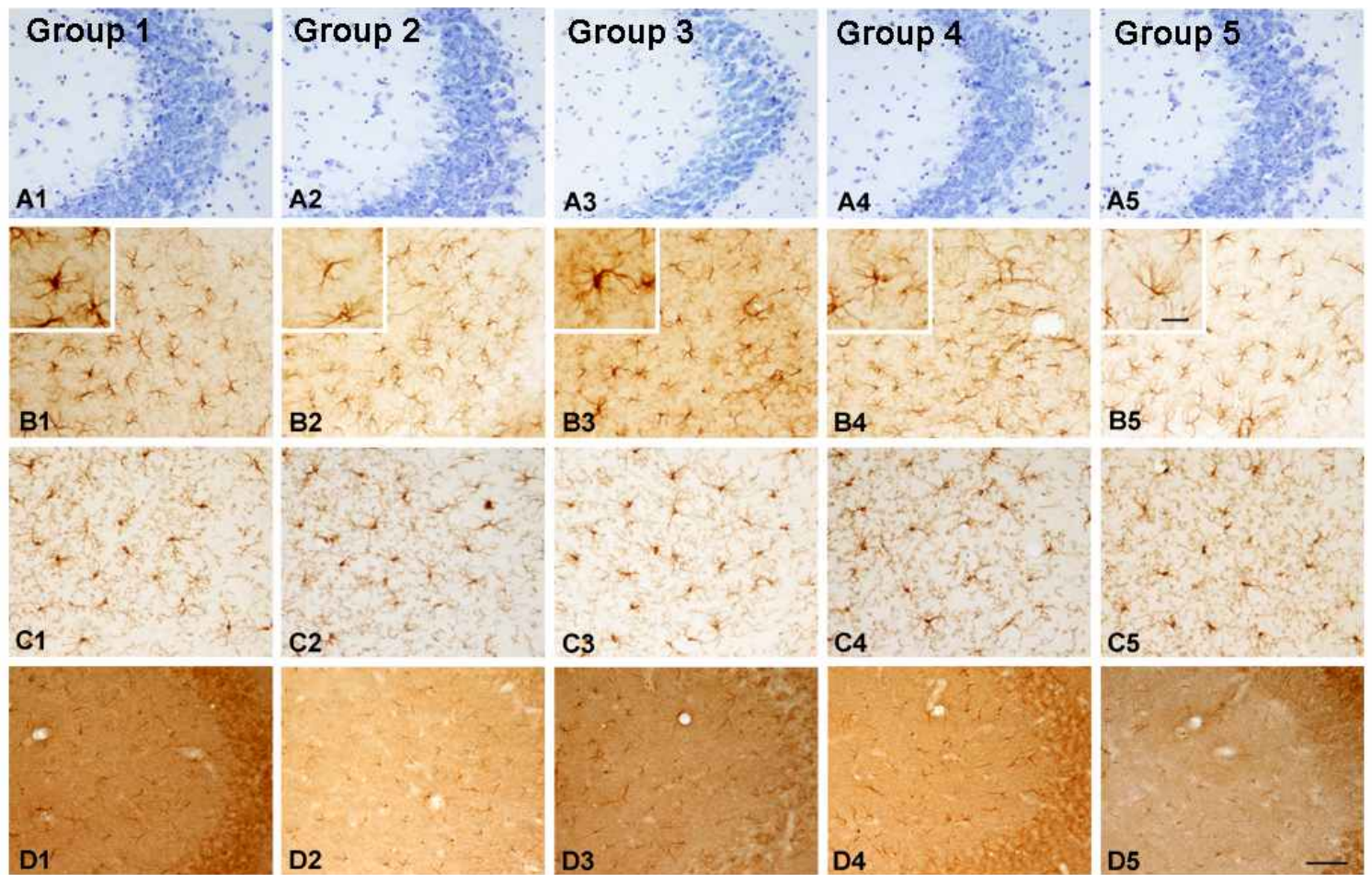

Fig. 4. Cresyl violet staining and GFAP, iba-1, and CD45 expression in the CA3 region of rmTBI. Representative cresyl-violet-stained images showed no pyramidal degeneration or chromatolysis in all groups (A). In groups 2, 4, and 5, GFAP+ astrocytes had tread-like processes and a small cytoplasm. In groups 1 and 3, GFAP+ astrocytes were in a mildly activated form with a hypertrophied cytoplasm and thickened process (B). The rectangular area in B is a higher magnification view of the CA3 region of each group. However, iba-1+ microglia in both groups had a small cytoplasm and a few thin processes. Many iba-1+ microglia were not hypertrophied or aggregated in all groups and exhibited a dense cytoplasm and a round morphology, indicating microglia activation (C). CD45+ macrophages/microglial cells were not observed in an activated form (D). Scale bars $=50 \mu \mathrm{m}$ in A-D and $20 \mu \mathrm{m}$ in the rectangular area in B1-4. 


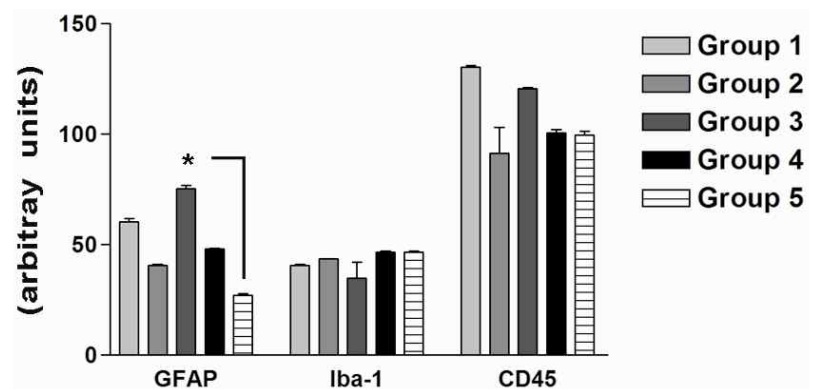

Fig. 5. Image analysis of the relative density of GFAP, iba-1, and CD45 in the CA3 region of rmTBI. The data shown are the means \pm standard deviation obtained from three independent experiments. ${ }^{*} p<0.05$ compared with group 5.

used for repeated impacts. We also believe that this model could be suitable for CTE, which is induced by repeated impacts.

As early as 1970, neurofibrillary tangles were reported in the neocortical areas of boxer with CTE [3]. Cortical tangles also constitute a key component of Alzheimer's disease. However, because they are found in many chronic neurological diseases with different etiologies, they may represent a more general response to neurodegenerative pathology [2]. Indeed, their abundance in CTE, which is caused by repeated brain trauma episodes, further supports that they may represent a response to brain damage. Tangles are found intracellularly in the cytoplasm of neurons and consist of thread-like aggregates of hyperphosphorylated tau protein [7]. Tau is a normal axonal protein that binds to microtubules via its microtubule-binding domain. Tau is frequently found in a hyperphosphorylated state, and it reduces microtubule binding, causing disassembly of microtubules and leading to compromised neuronal and synaptic function, increased propensity of tau aggregation, and subsequent formation of insoluble fibrils and tangles [13]. Therefore, phosphorylated tau could be a marker of CTE. However, identifying tau tangles in the mouse brain by immunohistochemistry is very difficult, but we consistently observe increases in phospho-tau expression after repeated mild head impacts (rmTBI) in mice. In fact, many methods of mild TBI claim to be models of "sports-related" head injury, and they do not cause increases in p-tau expression. Transgenic mice expressing human tau are interesting, but these mice have some serious problems without head injury so it is hard to judge the exact influence of head impacts on p-tau in their brains [16]. In this study, we confirmed the increase in $p$-tau expression after rmTBI, suggesting that the rmTBI model is potentially suitable for CTE, because experimental studies in animals suggested that tau phosphorylation may be consequences of repeated brain trauma.

Cerebrolysin is a mixture of neurotrophic factors and peptides that could act in the brain to attenuate oxidative or cellular stress $[22,23]$. The reduction in oxidative stress in TBI mediated by cerebrolysin appears to be one of the most important effects of the drug in terms of inducing neuroprotection [8]. In the current study, we found that p-tau expression was decreased in the cortex and CA3 after rmTBI following intra-tail vein injection of cerebrolysin, suggesting that cerebrolysin can confer neuroprotection against the detrimental effects of rmTBI.

Gavett et al. offered a general description of how the damage occurs through the repeated traumatic injury of axons. Damage to axons affects membrane permeability and causes ionic shifts, resulting in a large influx of calcium. Subsequent release of caspases and calpains would trigger tau phosphorylation, misfolding, shortening, and aggregation, as well as cytoskeleton failure with dissolution of neurofilaments and microtubules [6]. This idea was elaborated from the concept of immunoexcitotoxicity as a possible central mechanism in CTE. Blaylock and Maroon described a cascade of events that begins with an initial head trauma, which "activates" astrocytes and microglia for subsequent injuries [1]. Therefore, we evaluated astrocyte and microglia activation after TBI with or without cerebrolysin treatment. In the present study, we observed mild astrocyte activation but not microglia activation or infiltration of macrophages into the brain parenchyma, a finding that was consistent with that in a previous study [9]. We also found that astrocyte activation after rmTBI was reduced with cerebrolysin treatment. One study investigated the effects of cerebrolysin in primary microglial and astrocyte rat cell culture. They showed a protective effect of cerebrolysin as revealed by downregulation of microglial activation after lipopolysaccharide (LPS) treatment and regulation of IL-1 beta expression. No significant difference in astrocyte morphology, survival, or the production and/or release of BDNF was observed. Therefore, cerebrolysin might exert a neuroimmunotrophic effect that reduces the extent of inflammation and accelerate neuronal death under pathological conditions [12]. This discrepancy may be due to the use of in vivo animals vs. in vitro primary glial culture. Microglia cells play an important role in the immune system in the brain and are key mediators of the inflammatory response after TBI. However, in the current 
study, no morphological change or activation was found, as also reported by Kane et al. The microglial response is associated with upregulation of both pro- and anti-inflammatory genes, chemokines, and other inflammatory mediators in TBI [29]. Therefore, further investigation is warranted regarding whether modulation of this inflammatory response to TBI may have any therapeutic or detrimental effect.

\section{Acknowledgement}

This research was supported by Basic Science Research Program through the National Research Foundation of Korea (NRF) funded by the Ministry of Science, ICT and Future Planning (2013R1A1A1A05006966).

\section{References}

1. Blaylock, R. L. and Maroon, J. 2011. Immunoexcitotoxicity as a central mechanism in chronic traumatic encephalopathy-A unifying hypothesis. Surg Neurol Int 2, 107.

2. Blennow, K., Hardy, J. and Zetterberg, H. 2012. The neuropathology and neurobiology of traumatic brain injury. Neuron 76, 886-899.

3. Corsellis, J. A., Bruton, C. J. and Freeman-Browne, D. 1973. The aftermath of boxing. Psychol Med 3, 270-303.

4. Foda, M. A. and Marmarou, A. 1994. A new model of diffuse brain injury in rats. Part II: Morphological characterization. J Neurosurg 80, 301-313.

5. Fourtassi, M., Hajjioui, A., Ouahabi, A. E., Benmassaoud, H., Hajjaj-Hassouni, N. and Khamlichi, A. E. 2011. Long term outcome following mild traumatic brain injury in Moroccan patients. Clin Neurol Neurosurg 113, 716-720.

6. Gavett, B. E., Stern, R. A. and McKee, A. C. 2011. Chronic traumatic encephalopathy: a potential late effect of sport-related concussive and subconcussive head trauma. Clin Sports Med 30, 179-188.

7. Grundke-Iqbal, I., Iqbal, K., Tung, Y. C., Quinlan, M., Wisniewski, H. M. and Binder, L. I. 1986. Abnormal phosphorylation of the microtubule-associated protein tau (tau) in Alzheimer cytoskeletal pathology. Proc Natl Acad Sci USA 83, 4913-4917.

8. Guzman, D. C., Brizuela, N. O., Alvarez, R. G., Garcia, E. H., Mejia, G. B. and Olguin, H. J. 2009. Cerebrolysin and morphine decrease glutathione and 5-hydroxyindole acetic acid levels in fasted rat brain. Biomed Pharmacother 63, 517-521.

9. Kane, M. J., Angoa-Perez, M., Briggs, D. I., Viano, D. C., Kreipke, C. W. and Kuhn, D. M. 2012. A mouse model of human repetitive mild traumatic brain injury. $J$ Neurosci Methods 203, 41-49.

10. Kim, D. W., Lee, J. H., Park, S. K., Yang, W. M., Jeon, G. S., Lee, Y. H., Chung, C. K. and Cho, S. S. 2007. Astrocytic expressions of phosphorylated Akt, GSK3beta and CREB following an excitotoxic lesion in the mouse hippocampus. Neurochem Res 32, 1460-1468.

11. Lee, Y. S., Kang, J. W., Lee, Y. H. and Kim, D. W. 2011. ID4 mediates proliferation of astrocytes after excitotoxic damage in the mouse hippocampus. Anat Cell Biol 44, 128-134.

12. Lombardi, V. R., Windisch, M., Garcia, M. and Cacabelos, R. 1999. Effects of Cerebrolysin on in vitro primary microglial and astrocyte rat cell cultures. Methods Find Exp Clin Pharmaco 21, 331-338.

13. Mandelkow, E. M. and Mandelkow, E. 2012. Biochemistry and cell biology of tau protein in neurofibrillary degeneration. Cold Spring Harb Perspect Med 2, a006247.

14. Marmarou, A., Foda, M. A., van den Brink, W., Campbell, J., Kita, H. and Demetriadou, K. 1994. A new model of diffuse brain injury in rats. Part I: Pathophysiology and biomechanics. J Neurosurg 80, 291-300.

15. McKee, A. C., Cantu, R. C., Nowinski, C. J., Hedley-Whyte, E. T., Gavett, B. E., Budson, A. E., Santini, V. E., Lee, H. S., Kubilus, C. A. and Stern, R. A. 2009. Chronic traumatic encephalopathy in athletes: progressive tauopathy after repetitive head injury. J Neuropathol Exp Neurol 68, 709-735.

16. Ojo, J. O., Mouzon, B., Greenberg, M. B., Bachmeier, C., Mullan, M. and Crawford, F. 2013. Repetitive mild traumatic brain injury augments tau pathology and glial activation in aged hTau mice. J Neuropathol Exp Neurol 72, 137-151.

17. Omalu, B. I., Bailes, J., Hammers, J. L. and Fitzsimmons, R. P. 2010. Chronic traumatic encephalopathy, suicides and parasuicides in professional American athletes: the role of the forensic pathologist. Am J Forensic Med Pathol 31, 130132.

18. Omalu, B. I., Hamilton, R. L., Kamboh, M. I., DeKosky, S. T. and Bailes, J. 2010. Chronic traumatic encephalopathy (CTE) in a National Football League Player: Case report and emerging medicolegal practice questions. J Forensic Nurs 6, 40-46.

19. Ren, J., Sietsma, D., Qiu, S., Moessler, H. and Finklestein, S. P. 2007. Cerebrolysin enhances functional recovery following focal cerebral infarction in rats. Restor Neurol NeuroSci 25, 25-31.

20. Saulle, M. and Greenwald, B. D. 2012. Chronic traumatic encephalopathy: a review. Rehabil Res Prac 2012, 816069.

21. Sharma, H. S. 2007. A select combination of neurotrophins enhances neuroprotection and functional recovery following spinal cord injury. Ann N Y Acad Sci 1122, 95-111.

22. Sharma, H. S., Zimmermann-Meinzingen, S. and Johanson, C. E. 2010. Cerebrolysin reduces blood-cerebrospinal fluid barrier permeability change, brain pathology, and functional deficits following traumatic brain injury in the rat. Ann $N$ Y Acad Sci 1199, 125-137.

23. Sharma, H. S., Zimmermann-Meinzingen, S., Sharma, A. and Johanson, C. E. 2010. Cerebrolysin attenuates bloodbrain barrier and brain pathology following whole body hyperthermia in the rat. Acta Neurochir Suppl 106, 321-325.

24. Stern, R. A., Riley, D. O., Daneshvar, D. H., Nowinski, C. J., Cantu, R. C. and McKee, A. C. 2011. Long-term con- 
sequences of repetitive brain trauma: chronic traumatic encephalopathy. PM\&R 3, S460-467.

25. Thurman, D. J., Branche, C. M. and Sniezek, J. E. 1998. The epidemiology of sports-related traumatic brain injuries in the United States: recent developments. I Head Trauma Rehabil 13, 1-8.

26. Ubhi, K., Rockenstein, E., Doppler, E., Mante, M., Adame, A., Patrick, C., Trejo, M., Crews, L., Paulino, A., Moessler, H. and Masliah, E. 2009. Neurofibrillary and neurodegenerative pathology in APP-transgenic mice injected with AAV2-mutant TAU: neuroprotective effects of Cerebrolysin. Acta Neuropathol 117, 699-712.
27. Viano, D. C., Hamberger, A., Bolouri, H. and Saljo, A. 2012. Evaluation of three animal models for concussion and serious brain injury. Ann Biomed Eng 40, 213-226.

28. Yi, M. H., Lee, Y. S., Kang, J. W., Kim, S. J., Oh, S. H., Kim, Y. M., Lee, Y. H., Lee, S. D. and Kim, D. W. 2013. NFAT5dependent expression of AQP4 in astrocytes. Cell Mol Neurobiol 33, 223-232.

29. Ziebell, J. M. and Morganti-Kossmann, M. C. 2010. Involvement of pro- and anti-inflammatory cytokines and chemokines in the pathophysiology of traumatic brain injury. Neurotherapeutics 7, 22-30.

\section{초록 : 만성외상성뇌병증과 관련된 반복적 경도 외상성뇌손상 $(r \mathrm{rTB})$ 모델에서 cerebrolysin의 별아교 세포활성 억제효과 \\ 강현배 ${ }^{1} \cdot$ 김기훈 $^{2} \cdot$ 김현중 ${ }^{2} \cdot$ 한사랑 $^{3} \cdot$ 채동진 $^{3} \cdot$ 송희정 ${ }^{4} \cdot$ 김동운 $^{*}{ }^{*}$ \\ ( ${ }^{1}$ 질병관리본부 국립보건연구원 감염병센터 병원체자원관리TF, ${ }^{2}$ 대전대학교 생명과학과 면역질환생리생화학실, 3충남대학교 의학전문대학원 해부학교실, ${ }^{4}$ 충남대학교병원 신경과)}

만성외상성뇌병증(Chronic traumatic encephalopathy, CTE)은 운동선수와 매우 밀접하게 관련되어 있으며 장 기간에 걸쳐 반복적인 외상성뇌손상(traumatic brain injury, $\mathrm{TBI}$ 로 인한 퇴행성뇌질환이다. 신경영양인자 (neurotrophic factor)는 여러 종류가 알려져 있으며 이들은 뇌와 척수의 물리적 손상시에 신경보호효과가 있다. 따라서, 신경영양인자의 혼합물인 cebrolysin을 이용하여 CTE질환에 가장 적합하다고 여겨지는 repetitive mild TBI (rmTBI) 모델에서 cerebrolysin의 신경보호효과를 알아보고자 하였다. 실험군은 5군(groups 1 and 2: rmTBI for 4 weeks following cerebrolysin injection for 4 weeks; groups 3 and 4: rmTBI for 8 weeks with or without cerebrolysin injection for 4 weeks; group 5: control)으로 나누어 진행하였다. CTE의 가장 대표적 표시인자인 tau 단백질의 인산화를 조직학적으로 조사한 결과, 대뇌겉질과 해마내 CA3 영역에서 phospho-tau단백질의 발현이 증가되었으며 cerebrolysin $(10 \mu \mathrm{lof} 1 \mathrm{mg} / \mathrm{ml})$ 를 미정맥으로 투여시 p-tau발현이 감소되었다. CTE의 병인으로 알려진 별아교세포와 미세아교세포의 활성을 각각의 표시인인 GFAP, iba-1을 이용하여 면역조직화학염색을 시행 하였다. 별아교세포의 활성은 rmTBI에 의하여 증가하였으며 cerebrolysin에 의해 회복되었으나 미세아교세포의 활성은 관찰되지 않았다. 또한 rmTBI모델에서 체내 탐식세포(macrophage)의 뇌내유입유무를 관찰하고자 CD45 염색을 시행하였으나 유의한 차이를 관찰하지 못하였다. 이상의 결과를 종합하면, cerebrolysin이 rmTBI에 의한 tau단백질의 인산화 및 별아교세포의 활성을 조절하는 것으로 사료된다. 따라서 cerebrolysin이 CTE 환자에 대한 치료 약물의 후보가 될 수 있음을 시사한다. 